\title{
Sugar-sweetened beverages and sports sponsorship. The right to health of children and adolescents at stake
}

\author{
Social Anthropologist Laura R. Piaggio ${ }^{a}$
}

\begin{abstract}
Advertising of unhealthy foods and beverages to which children and adolescents are exposed has been identified as a factor of great relevance in the genesis, expansion and persistence of obesity. This article deals with sports sponsorship by companies producing sugar-sweetened drinks and their influence on the preferences of hydration, purchasing, intention and consumption habits. It highlights the negative health consequences from the consumption of sugary drinks (soft drinks and sports beverages) and their association with obesity and risk of metabolic and cardiovascular diseases. There is a need to apply the legal principle of "best interests of the child" to demand the protection of the right to health, in line with the recommendations of international health organizations for the restriction of advertising of unhealthy foods and beverages targeted at children and adolescents. Key words: Carbonated beverages, Food publicity, Sports, Childhood obesity, Right to health.
\end{abstract}

http:/ / dx.doi.org/10.5546/ aap.2019.eng.e8

To cite: Piaggio LR. Sugar-sweetened beverages and sports sponsorship. The right to health of children and adolescents at stake. Arch Argent Pediatr 2019;117(1):e8-e13.

\section{INTRODUCTION}

Childhood obesity is one of the most serious public health problems both worldwide and in Argentina.

a. Instituto Universitario de Ciencias de la Salud "H. Barceló", Ciudad Autónoma de Buenos Aires.

E-mail address:

Laura R. Piaggio: piaggiolau@gmail.com

Funding:

None.

Conflict of interest: None.

Received: 2-21-2018 Accepted: 6-28-2018
According to World Health Statistics $2017,{ }^{1}$ the prevalence of obesity among children under 5 years of age accounts to $6 \%$ at a global level, Argentina reporting $9.9 \%$. In adolescents aged 13 to 15 years, the Global SchoolBased Student Health Survey for the year 2012 recorded a $28.6 \%$ of students suffering from overweight. ${ }^{2}$

Advertisements of unhealthy foods and drinks to which children and adolescents are exposed has been identified as a factor of great relevance in the genesis, expansion and persistence of the obesity. ${ }^{3-6}$
Advertising these products has become omnipresent, using multifaceted and integrated advertising techniques, which prove to be attractive for children and adolescents. ${ }^{4}$

Faced with this situation, most research works have studied television food advertising, ${ }^{7}$ to a lesser extent some studies have focused on advertising through packages ${ }^{8}$ and, more recently, some research has been done about digital media advertising. ${ }^{9}$ In our country, it have been developed studies that analyze the nutritional profile of the products advertised to children through television ${ }^{10,11}$ and packaging, ${ }^{12,13}$ at the same time that describe the advertising resources used. Sports sponsorship has been studied less frequently, ${ }^{14}$ although it entails advertising strategies of vital importance in marketing campaigns of companies producing foods, drinks and unhealthy fast foods. ${ }^{15,16}$

The most advertised products through sports sponsorship are sugar-sweetened drinks (mainly soft drinks and sports beverages). There is a lot of scientific evidence that associates the consumption of sugarsweetened drinks with the prevalence of childhood and adult obesity, as well as other non-communicable chronic illnesses, like diabetes.

It is at least paradoxical for unhealthy products, such as sugarsweetened drinks (table 1), to be advertised through sports (an activity generating well-being and health benefits). This situation proves to be even more worrisome in terms of public health when the population participating in the sponsored sports event is made up of children and adolescents. 


\section{EFFECTS FROM EXPOSURE TO UNHEALTHY FOOD AND DRINK ADVERTISING}

The influence of advertising on children's and adolescents' eating habits, favoring the consumption of foods and drinks high in sugars, fats and/or sodium, whose intake is closely associated with obesity, has been reliably documented in abundant, robust literature.

Already in 2005, Lobstein and Dibb ${ }^{3}$ analyzed the link between exposure to advertising of unhealthy foods and drinks and child overweight, making a comparison in the USA, Australia and eight European countries using data collected about the quantity and type of television advertising, and surveys on the nutritional status of school-aged children. They found a significant association between the proportion of children suffering from overweight and the number of advertisements encouraging unhealthy products (high in sugars, fats and or sodium) per hour on television, postulating ecological evidence for such link.

Likewise, Cairns, Hastings, et al. ${ }^{4}$ have conducted periodical and complete systematic reviews of international evidence produced on the type and extent of advertising of foods and drinks targeted at children. They could establish that the most common categories of food products promoted to children are sugarsweetened drinks, pre-sugared breakfast cereals, candies and confectionery, snacks and fast foods. This advertising is mostly shown during children's programming than in adult primetime programming. Significant changes have been reported which are attributable to the exposure to advertisements regarding food preferences and consumption, such as an increase in "pecking", a greater consumption of calories and fewer choices of healthy options ${ }^{4}$.

Along these lines, a recent meta-analysis ${ }^{5}$ consolidated experimental studies that measured the impact of advertising of unhealthy foods and drinks on consumption. The authors could clearly establish that exposure to advertising increases the intake of unhealthy food and drinks in children, concluding that these findings provide strong evidence to support regulatory public health policy action.

\section{ADVERTISING ADDRESSED TO CHILDREN AND ADOLESCENTS THROUGH SPORTS SPONSORSHIP}

Sports sponsorship is one of the forms of advertising to which children are exposed. ${ }^{18} \mathrm{It}$ includes different levels of sports competitions, from school to national, regional and international tournaments.

Australian researcher Bridget Kelly ${ }^{18-20}$ has delved into different aspects of sports sponsorship. She studied the way that it is perceived by children, as well as their purchasing and consumption attitudes and behaviors. She collected data about significant brand recognition and a positive appraisal of such brands ("they are cool"), as well as their assertion about having bought the product as way of "returning the favor" for supporting their favorite sports. Likewise, $86 \%$ of the children surveyed in one of the studies conducted by Kelly reported having received vouchers, product samples or certificates bearing the name of the company sponsoring the club where they regularly do physical activity, expressing a great deal of content in this sense. ${ }^{18}$

Another frequent situation is sports celebrity sponsorship, a strategy that has proven to have a powerful persuasive effect, influencing children's vision of their eating requests (need for more energy, a "sugar peak " or sports drinks) to improve their sports performance, thus influencing them at the time of purchasing or consuming the products being promoted. ${ }^{21}$

A wide and strict systematic review published in 2017 synthesized quantitative and qualitative research examining children and adult opinions on the sport-related food environment. ${ }^{22}$ Parents and caretakers considered that the eating environment in clubs or other places

TABLE 1. Added sugar content in soft drinks and sports drinks (500 ml per bottle)

\begin{tabular}{lccc}
\hline Beverages categories & $\begin{array}{c}\text { Average sugar } \\
\text { in total of category } \\
\text { beverages }\end{array}$ & $\begin{array}{c}\text { Proportion in \% of } \\
\text { the "strong" WHO } \\
\text { recommendation (50 g daily) }\end{array}$ & $\begin{array}{c}\text { Proportion in \% of } \\
\text { the WHO “conditional" } \\
\text { recommendation (25 g daily) }\end{array}$ \\
\hline Regular soft drinks & $54.75 \mathrm{~g}$ & $109 \%$ & $219 \%$ \\
Sports drinks & $30.00 \mathrm{~g}$ & $60 \%$ & $120 \%$ \\
\hline
\end{tabular}

WHO: World Health Organization.

Source: own elaboration based on data from FIC Argentina. ${ }^{17}$. 
for sports practice did not favor healthy eating behaviors, since most of the products offered and / or promoted were high-calorie and poor in nutrients, proving to be inconsistent with the healthy nature of sports. They considered that resorting to sports to promote unhealthy foods and drinks gave confusing and contradictory messages to children, since they are in fact "endorsing" the consumption of junk food, by linking junk food to the prestige of the club or celebrity being sponsored and to the fondness for a sports discipline.

Recently, a research conducted in USA ${ }^{23}$ evaluated the exposure of children and adolescent to sponsorship of sporting events on television and digital media, and showed that $70 \%$ of the advertised products had a inadequate profile of nutrients and that sports sponsorship exposed millions of people to such advertising.

Taking into account this scientific evidence concerning the magnitude of exposure and the influence of sports sponsorship in children's food perceptions and practices, ${ }^{24}$ the high penetration of sugar-sweetened drinks involving sponsored tournaments and sports figures proves to be alarming.

In Argentina, the main soft-drinks company sponsors an inter-school tournament, organized for high school students aged 13 to 15 years. During the games, students are given a carbonated or sport drink bottle as a refreshment.

Moreover, as a global partner of the International Olympic Committee's (OIC), the same company has sponsored several editions of the Games, including the new Youth Olympic Games (YOG), with the participation of teenage athletes aged 15 to 18 years. These games started up in 2010 and they took place for the third time in their summer version in the City of Buenos Aires in October 2018. During twelve days, about 4,000 young people from 206 countries took part in competitions. In different preparatory YOG events, directed to the general public (Olympic International Day Celebrations, Buenos Aires Festival 2018) and young Argentine sportspeople (Official Campus in Argentine High Performance Sports Center), graphic and three-dimensional advertisements were shown, and sports beverage bottles were distributed as the drink nominated as the "official hydrator" at the Buenos Aires 2018 YOG.

After including the Olympic rings on the containers and graphic advertisements, designing TV spots and digital networks, accompanying the journey of the Olympic torch, delivering brochures and product samples, including multimedia facilities at the Olympic parks, acquiring selling exclusive rights at the gastronomic premises there, among other marketing strategies, ${ }^{25}$ the Olympic Games give the largest world producer of sugar-sweetened drinks an unprecedented opportunity to advertise their products, ${ }^{26}$ especially catching children's and adolescents' attention. ${ }^{25}$

\section{NEGATIVE IMPACT OF SUGAR- SWEETENED DRINKS ON CHILDHOOD HEALTH}

Scientific evidence proves solid when it comes to linking the increased consumption of sugarsweetened drinks with the epidemic of obesity. Several systematic reviews and meta-analysis have established a clear association between the intake of sugar-sweetened drinks and the increase in caloric intake, as well as the resulting body weight gain, both in children as in adults. ${ }^{27,28}$ At the same time, it has been established that they lead to the development of abdominal and ectopic adiposity, the latter being associated with the metabolic syndrome. ${ }^{27}$

In a study carried out in Mexico ${ }^{29}$ involving a cohort of children, researchers established that $73 \%$ of the children began to take sugar-sweetened drinks before 12 months of age and, by the time they were 24 months old, $100 \%$ of the children had already initiated consumption. The children who reported a bigger consumption during the pre-school period had 3 times higher odds of having general and abdominal obesity at the age of 8 .

In our country, the National Nutrition and Health Survey ${ }^{30}$ documented that $46 \%$ of children under 2 years of age consumed sugar-sweetened beverages, while the School Health Survey ${ }^{2}$ established that 1 in 2 adolescents drunk them 2 or more times a day, and a study ${ }^{31}$ conducted in province of Salta identified that $73,7 \%$ of adolescents consumed sugar-sweetened beverages frecuently ( $>3$ times a week).

In another study involving a cohort of adolescents in the USA, ${ }^{32}$ the research was focused on investigating consumption of sports drinks and their link with weight gain. It was established that each daily serving of sports drink predicted an increase of 0.3 and 0.33 points of Body Mass Index in women and men, respectively. Therefore, their consumption was associated with a higher weight gain and obesity risk. The authors 
argue that public health measures oriented to preventing childhood obesity, such as restricting the sale of sugar-sweetened drinks at schools, should include not only soft drinks but also sports drinks, which are strongly advertised and promoted as part of an "active lifestyle". The authors also maintain that there is no evidence revealing the benefit of their consumption in the general population, taking into account not only their contents of added sugars (an average of $30 \mathrm{~g}$ per bottle of $500 \mathrm{ml})$, but also of sodium $(300 \mathrm{mg}$ ), whose intake also needs to be decreased so as to reduce cardiovascular disease morbidity and mortality.

It should be highlighted that children with obesity have an increased risk of suffering comorbidities such as type II diabetes, fatty liver, endocrine disorders and orthopedic problems. At the same time, they have higher odds of keeping their obesity in adulthood, which increases the risk of metabolic and cardiovascular diseases. ${ }^{3}$

\section{PROTECTION OF THE RIGHT TO HEALTH AT STAKE}

Argentina is among the four larger consumers of sugar-sweetened drinks worldwide, with an average of 133 liters per capita on a yearly basis. ${ }^{33}$

Sports sponsorship, either school, professional or high-performance, proves problematical since it amounts to an advertising strategy that is strongly targeted at children and adolescents.

Promoting drinks high in sugars (and, in some cases, in sodium) may weaken the health benefits contributed by sports activities; moreover, it sets unhealthy hydration practices which may endure throughout a person's lifetime. ${ }^{20,34,35}$

Hence, sponsorship contributes towards the creation in children and adolescents brand recognition, a habitual taste and emotional bonds with the products.

Moreover, sports sponsorship creates in adults a positive image of brands and companies, trying to keep their credibility. ${ }^{15} \mathrm{~A}$ central strategy in handling the public image of companies producing sugar-sweetened drinks is precisely showing themselves as entities that are engaged with the promotion of "an active and healthy lifestyle". This constructed image works like a "smokescreen" ${ }^{15}$ seeking to hide adverse health effects caused by their products while promoting them at the same time.

Furthermore, this strategy aims to present sponsorship as an action of corporate or philanthropic responsibility, when in fact it constitutes an advertising strategy ${ }^{20}$ and a tool to resist regulatory initiatives. ${ }^{15}$

Amid this context, it is necessary to dismantle that shield of arguments and prioritize the legal principle concerning the "best interests of the child", established in the International Convention on the Rights of the Child, which has constitutional status in Argentina since 1994.

Argentina's Federal Act No. 26061 dealing with the Comprehensive Protection of the Rights of the Children and Adolescents, ${ }^{36}$ and Act No. $144^{37}$ prevailing in the City of Buenos Aires, define the best interests of children and adolescents as "the integral system composed by each and every of their rights already protected and the ones that may be protected in the future". Among the protected rights, it is worth mentioning the right to protection of health.

There is an important documentary corpus elaborated by international organizations (World Health Organization, ${ }^{38}$ Pan American Health Organization, ${ }^{39}$ United Nations High Commissioner for Human Rights), ${ }^{40}$ which establishes regulations for advertising addressed to children and adolescents as a necessary course of action to achieve a comprehensive protection of their health.

In particular, it is argued that all environments where children and adolescents develop their everyday activities (schools, settings dedicated to physical and/or recreational activity, among others) should ban the use of advertisements "of foods high in saturated fats, trans fatty acids, free sugars or salt (Recommendation 5). ${ }^{38}$

Consequently, it is necessary to visualize sports sponsorship by companies of sugarsweetened drinks as a marketing strategy that exposes children and adolescents to advertising of unhealthy drinks, a situation which is particularly worrisome in those events where young people are the protagonists.

It is worthy to mention that, in Argentina, there are Acts ${ }^{41,42}$ referred to food publicity that forbiden misleading advertising or that induces behaviors harmful to health, but they aren't explicitly appointed to reduce the exposure of children and adolescent to unhealthy food and beverages advertisements. ${ }^{11}$

This violates their right to health and reveals that the State fails to comply with its obligation to protect such right. ${ }^{43}$ It is of utmost importance that this violation and non-fulfillment be included in the public agenda. In this sense, civil society organizations (academic and professional 
organizations, organizations in charge of defending the rights of children and adolescents, and of consumers, among others) have a lot to contribute. ${ }^{44,45}$

Quoting Anand Grover, the United Nations Special Rapporteur on the Right to Health, we believe that "the responsibility to protect the enjoyment of the right to health warrants State intervention in situations when third parties, such as food companies, use their position to influence dietary habits by directly or indirectly encouraging unhealthy diets, which negatively affect people's health. (...) States are especially required to protect vulnerable groups such as children from violations of their right to health". ${ }^{40}$

\section{REFERENCES}

1. World Health Statistics 2017: monitoring health for the SDGs, Sustainable Development Goals. Geneva: World Health Organization; 2017. [Consulta: 24 de enero de 2018]. Disponible en: http://apps.who.int/iris/bitstre $\mathrm{am} / 10665 / 255336 / 1 / 9789241565486$-eng.pdf?ua=1.

2. Ministerio de Salud de la Nación. Boletín de Vigilancia de Enfermedades no Transmisibles y Factores de Riesgo. Obesidad. Buenos Aires: MSAL; 2016(8). [Consulta: 1 de diciembre de 2017]. Disponibleen:http:/ / www.msal.gob. ar/ent/images/stories/vigilancia/pdf/2016-2_boletinde-vigilancia-8.pdf.

3. Lobstein T, Dibb S. Evidence of a possible link between obesogenic food advertising and child overweight. Obes Rev. 2005; 6(3):203-8.

4. Cairns G, Angus K, Hastings G, Caraher M. Systematic reviews of the evidence on the nature, extent and effects of food marketing to children. A retrospective summary. Appetite. 2013; 62:209-15.

5. Boyland E, Nolan S, Kelly B, et al. Advertising as a cue to consume: a systematic review and meta-analysis of the effects of acute exposure to unhealthy food and nonalcoholic beverage advertising on intake in children and adults. Am J Clin Nutr. 2016; 103(2):519-33.

6. Mallarino C, Gómez L, González-Zapata L, et al. Advertising of ultra-processed foods and beverages: children as a vulnerable population. Rev Saude Publica. 2013; 47(5):1006-10.

7. Kelly B, Halford J, Boyland E, et al. Television Food Advertising to Children: A Global Perspective. Am J Public Health. 2010; 100(9):1730-6.

8. Elliot C. Marketing Fun Food: a profile and analysis of supermarket food messages targeted at children. Can Public Policy. 2008; 34(2):259-74.

9. World Health Organization. Tackling food marketing to children in a digital world: trans-disciplinary perspectives. Copenhagen: WHO Regional Office for Europe; 2016. [Consulta:26deenerode2018].Disponibleen:http:/ / www. euro.who.int /__data/assets / pdf_file / 0017/322226/ Tackling-food-marketing-children-digital-world-transdisciplinary-perspectives-en.pdf.

10. Rovirosa A, Zapata ME, Gómez P, etal. Alimentos y bebidas publicitados en canales infantiles de Argentina: frecuencia, duración y calidad nutricional. Arch Argent Pediatr. 2017; 115(1):28-34.

11. Allemandi L, Castronuovo L, Tiscornia MV, et al. Food advertising on Argentinean television: are ultra-processed foods in the lead? Public Health Nutr. 2017; 21(1):238-46.
12. Piaggio L, Solans A. Diversión ultra-procesada: productos alimenticios dirigidos a niños y niñas en supermercados de Argentina. Aproximación a las estrategias publicitarias y la composición nutricional. Diaeta. 2017; 35(159):9-16.

13. Fundación InterAmericana del Corazón Argentina. Informe de investigación: Rotulado facultativo y técnicas de marketing dirigidas a niños y niñas en envases de alimentos procesados de Argentina. Buenos Aires, mayo de 2017. [Consulta: 26 de mayo de 2018]. Disponibleen:http:/ / www.ficargentina.org/wp-content/ uploads/2017/11/1708_informe_envases_completo.pdf.

14. Carter M, Edwards R, Signal L, Hoek J. Availability and marketing of food and beverages to children through sports settings: a systematic review. Public Health Nutr. 2011; 15(8):1373-9.

15. Gómez L, Jacoby E, Ibarra L, et al. Sponsorship of physical activity programs by the sweetened beverages industry: public health or public relations? Rev Saude Publica. 2011; 45(2):423-7.

16. Maher A, Wilson N, Signal L, Thomson G. Patterns of sports sponsorship by gambling, alcohol and food companies: an Internet survey. BMC Public Health. 2006; 6:95.

17. Fundación InterAmericana del Corazón Argentina. Informe de investigación: Análisis de los niveles de azúcares agregados en las bebidas azucaradas no alcohólicas en Argentina. Buenos Aires, noviembre de 2014. [Consulta: 27 de junio de 2018]. Disponible en: http://www. ficargentina.org/wp-content/uploads/2017/11/informe_ azucar_19_11_2014.pdf.

18. Kelly B, Baur L, Bauman A, et al "Food company sponsors are kind, generous and cool": (mis)conceptions of junior sports players. Int J Behav Nutr Phys Act. 2011; 8:95.

19. Kelly B, Chapman K, King L, et al. Double standards for community sports: promoting active lifestyles but unhealthy diets. Health Promot J Austr. 2008; 19(3):226-8.

20. Kelly B. Food and Beverage Company Sponsorship of Children'sSport:Publicity orPhilanthropy?[Thesis].Sydney: The University of Sydney; 2012. 468 p. [Consulta: 27 dejunio de 2018]. Disponible en: https:/ / ses.library.usyd.edu.au/ bitstream/2123/8594/3/Kelly_Thesis_2012.pdf.

21. Phillipson L, Jones S. I eat Milo to make me run faster: how the use of sport in food marketing may influence the food beliefs of young Australians. In: D. Spanjaard S, Denize S, Sharma N. (eds). Proceedings of the Australian and New Zealand Marketing Academy Conference. Sydney, Australia: Australian and New Zealand Marketing Academy; 2008.P.1-7.

22. Smith M, Signal L, Edwards R, Hoek J. Children's and parents' opinions on the sport-related food environment: a systematic review. Obes Rev. 2017; 18(9):1018-39.

23. Bragg M, Miller A, Roberto C, et al. Sports sponsorships of food and nonalcoholic beverages. Pediatrics. 2018; 141(4):e20172822.

24. Carter M, Signal L, Edwards R, et al. Food, fizzy, and football: promoting unhealthy food and beverages through sport. New Zealand case study. BMC Public Health. 2013; 13:126.

25. Clark M, Brownell R. The obesity games. Children's Food Campaign. Sustain: the alliance for better food and farming. London, 2012. [Consulta: 24 de enero de 2018]. Disponible en: https: / / www.sustainweb.org/publications / the obesity_games/.

26. IOC and Coca-Cola extend partnership to 2020. [Consulta: 26 de mayo de 2018]. Disponibleen: https:/ / www.olympic. org/news/ioc-and-coca-cola-extend-partnership-to-2020.

27. Vartanian L, Schwartz M, Brownell K. Effects of soft drink consumption on nutrition and health: a systematic review and meta-analysis. Am J Public Health. 2007; 97(4):667-75. 
28. Malik VS, Pan A, Willett W, Hu FB. Sugar-sweetened beverages and weight gain in children and adults: a systematic review and meta-analysis. Am J Clin Nutr. 2013; 98(4):1084-102.

29. Cantoral A, Téllez-Rojo M,Ettinger A, etal.Early introduction and cumulative consumption of sugar-sweetened beverages during the pre-school period and risk of obesity at 8-14 years of age. Pediatr Obes. 2016; 11(1):68-74

30. Mangialavori G, Abeyá Gilardon E, Biglieri Guidet A, et al. La alimentación de los niños menores de 2 años. Resultados de la Encuesta Nacional de Nutrición y Salud (ENNyS). Buenos Aires: Ministerio de Salud de la Nación, 2010. [Consulta: 26 de mayo de 2018]. Disponible en: http:/ / www.msal.gob.ar/images/stories/bes / graficos / $0000000258 \mathrm{cnt}$-a09-alimentacion-de-ninosmenores-de-2-anos.pdf.

31. Gotthelf S, Tempestti C, Alfaro S, Cappelen L. Consumo de bebidas azucaradas en adolescentes escolarizados de la provincia de Salta. Centro Nacional de Investigaciones Nutricionales, 2014. Actual Nutr. 2015; 16(1):23-30.

32. Field A, Sonneville K, Falbe J, et al. Association of sports drinks with weight gain among adolescents and young adults. Obesity (Silver Spring). 2014; 22(10):2238-43.

33. Centrode Estudios de Estadoy Sociedad.Proyecto BASTA: Bebidas azucaradas, salud y tarifas en Argentina. Buenos Aires: CEDES; 2017. [Consulta: 26 de enero de 2018]. Disponible en: http: / / www.cedes.org/basta/.

34. Hawkes C. Marketing food to children: the global regulatory environment. Geneva: World Health Organization; 2004. [Consulta: 26 de mayo de 2018]. Disponible en: https:/ / nepc.colorado.edu/publication/marketing-food-childrenthe-global-regulatory-environment.

35. Taylor A, Jacobson M. Carbonating the world. The marketing and health impact of sugar drinks in low- and middle-income countries. Washington: Center for Science in the Public Interest. Washington; 2012. Consulta: 26 de mayo de 2018]. Disponible en: https: / / cspinet.org/ sites / default / files/attachment/ carbonatingreport.pdf.

36. Ley $\mathrm{N}^{\circ}{ }^{\circ} 26061$. Ley de protección integral de los derechos de las niñas, niños y adolescentes. InfoLEG. Buenos Aires, Argentina; 21 de octubre de 2005. [Consulta: 26 de enero de 2018]. Disponible en: http: / / servicios.infoleg.gob.ar/ infolegInternet/anexos / 110000-114999/110778/norma. htm.

37. Ley N. ${ }^{\circ} 114 / 98$. Ley de protección integral de los derechos delas niñas, niños y adolescentes. Legislatura de la Ciudad Autónoma de Buenos Aires, Argentina; 3 de diciembre de 1998. [Consulta: 26 de enero de 2018]. Disponible en: https: / / tinyurl.com/ley114CABA.

38. Organización Mundial de la Salud. Conjunto de recomendaciones sobre la promoción de alimentos y bebidas no alcohólicas dirigida a los niños. Ginebra: OMS; 2010. [Consulta: 26 de enero de 2018]. Disponible en: http:/ / apps.who.int/iris/itstream/10665/44422/1/97892 43500218_spa.pdf.

39. Organización Panamericana delaSalud. Recomendaciones dela Consulta deExpertos dela Organización Panamericana de la Salud sobre la promoción y publicidad de alimentos y bebidas no alcohólicas dirigida a los niños en la Región de las Américas. Washington: OPS; 2011. [Consulta: 26 de enero de 2018]. Disponible en: http://www.paho. org $/$ hq / index.php?option=com_docman\&task $=$ doc view\&gid $=18285 \&$ Itemid $=270$.

40. Grover A. Informe del Relator Especial sobre el derecho de toda persona al disfrute del más alto nivel posible de salud física y mental.(AHRC/26/31). Naciones Unidas, Consejo de Derechos Humanos. 2014. [Consulta: 26 de enero de 2018]. Disponible en: http: / / undocs.org/es / A / $\mathrm{HRC} / 26 / 31$.

41. Ley $\mathrm{N}^{\circ} 24240$. Defensa del Consumidor. InfoLEG. Buenos Aires Argentina; 13 de octubre de 1993. [Consulta: 26 de mayo de 2018]. Disponible en: http://servicios.infoleg. gob.ar/infolegInternet/anexos / 0-4999/638/texac.htm

42. Ley N. ${ }^{\circ}$ 26522. Servicios de Comunicación Audiovisual. InfoLEG. Buenos Aires, Argentina; 10 de octubre de 2009. [Consulta: 26 de mayo de 2018]. Disponible en: http:/ / servicios.infoleg.gob.ar/infolegInternet/ anexos/155000-159999/158649/norma.htm.

43. Granheim S, Vandevijvere S, Torheim L. The potential of a human rights approach for accelerating the implementation of comprehensive restrictions on the marketing of unhealthy foods and non-alcoholic beverages to children. Health Promot Int. 2018 [Epub ahead of print].

44. Kraak V, Vandevijvere S, Sacks G, et al. Progress achieved in restricting the marketing of high-fat, sugary and salty food and beverage products to children. Bull World Health Organ. 2016;94(7):540-8.

45. Alianza por la salud alimentaria. Demandan a FMF y FIFA no utilizar a niñas y niños como objetos publicitarios y menos de productos que dañan su salud. México, 2017. [Consulta: 26 de mayo de 2018]. Disponible en: http:/ / elpoderdelconsumidor.org/wp-content/ uploads / 2017 / 06/ b-demandan-a-fmf-y-fifa-no-utilizarninios-publicitando.pdf. 